\title{
STANDARISASI PARAMETER NON SPESIFIK DAN PERBANDINGAN KADAR KURKUMIN EKSTRAK ETANOL DAN EKSTRAK TERPURIFIKASI RIMPANG KUNYIT
}

\section{STANDARDIZATION OF NON SPECIFIC PARAMETER AND COMPARATIVE LEVELS OF CURCUMIN EXTRACT ETHANOL AND EXTRACT OF PURIFIED TURMERIC RHIZOME}

\author{
Barokati Azizah, Nina Salamah \\ Fakultas Farmasi Universitas Ahmad Dahlan Yogyakarta \\ Jl. Prof Dr. Supomo, Yogyakarta. Telp. (0274) 379418 \\ Email : syifaniputri@yahoo.com
}

\begin{abstract}
Abstrak
Kunyit (Curcuma domestica Val.) merupakan salah satu tanaman yang mengandung senyawa kurkumin dengan berbagai aktivitas. Pemanfaatan kurkumin dari rimpang kunyit yang banyak digunakan adalah dalam bentuk ekstrak etanol, namun masih terdapat zat ballast sehingga menyebabkan rendahnya kadar kurkumin. Hal ini dapat diupayakan dengan standarisasi ekstrak etanol yang terpurifikasi. Ekstrak etanol rimpang kunyit dibuat dengan metode maserasi menggunakan etanol 96 $\%$. Ekstrak etanol direndam dengan heksan hingga fase heksan terlihat jernih dan diperoleh ekstrak terpurifikasi yaitu fase tak larut heksan. Kadar kurkumin ditetapkan menggunakan metode Kromatografi Lapis Tipis (KLT) dengan fase diam silika gel $60 \mathrm{~F}$ dan fase gerak kloroform : etanol : asam asetat glasial (94:5:1) dan analisis kuantitatif menggunakan densitometri dengan panjang gelombang maksimum $426 \mathrm{~nm}$. Kadar air ekstrak ditetapkan menggunakan metode destilasi toluen, kadar abu dan kadar abu tidak larut asam ditetapkan menggunakan metode gravimetri. Hasil statistik dengan LSD menunjukkan perbedaan yang bermakna kadar kurkumin dan beberapa nilai parameter non spesifik pada ekstrak etanol dan ekstrak terpurifikasi.
\end{abstract}

Kata kunci : Curcuma domestica, kurkumin, ekstrak terpurifikasi, parameter non spesifik 


\section{Abstract}

Turmeric (Curcuma domestica Val.) is one of the plants that contain curcumin compounds with various activity. Use of curcumin from turmeric is widely used in the form of ethanolic extract, but there are ballast substances that cause low levels of curcumin. This can be pursued with the manufacture of a purified of ethanolic extract. Ethanolic extract of turmeric was made by maceration using ethanolic 96\%. Ethanolic extract soaked with hexane until the hexane phase is clear and purified extract obtained is insoluble hexane phase. Curcumin levels determined using Thin Layer Chromatography (TLC) method with the stationary phase silica gel $60 \mathrm{~F}$ and mobile phase of chloroform: ethanolic: glacial acetic acid (94: 5:1) and be analyzed quantitatively using densitometry with a maximum wavelength of $426 \mathrm{~nm}$. The water content of the extract determined using toluene distillation method, ash and acid insoluble ash content determined using gravimetric method. The statistic analysis with LSD showed significant differences of curcumin content and analysis of non-specific parameter values on ethanolic extract and purified extract.

Keywords : Curcuma domestica, curcumin, purified extract, non-specific parameter

\section{PENDAHULUAN}

Suatu simplisia tidak dapat dikatakan bermutu jika tidak memenuhi persyaratan mutu yang tertera dalam monografi simplisia. Persyaratan mutu yang tertera dalam monografi simplisia antara lain susut pengeringan, kadar abu total, kadar abu tidak larut asam, kadar sari larut air, kadar sari larut etanol, dan kandungan kimia simplisia meliputi kadar minyak atsiri dan kadar kurkuminoid. Persyaratan mutu ini berlaku bagi simplisia yang digunakan dengan tujuan pengobatan dan pemeliharaan kesehatan (Depkes, 2008).

Produk obat-obat herbal yang berkualitas ditentukan salah satunya oleh mutu dari bahan baku (simplisia) atau ekstrak yang digunakan. Kunyit merupakan salah satu bahan baku produk herbal yang banyak penggunaannya di
Indonesia. Komponen utama kunyit yang diketahui memiliki berbagai aktivitas adalah kurkumin, antara lain anti virus, anti jamur (Araujo dan Leon, 2001), anti oksidan (Jayaprakasha, et al., 2006), anti kanker (Anand, et al., 2008), antibiotik dan antiseptik (Pandey and Sanjay, 2010), anti inflamasi, anti diabetes, anti imunodefisiensi, anti aging, neuroprotective, anti koagulan, menurunkan lipid darah (Niazi, et al., 2010).

Ekstrak sebagai bahan dan produk kefarmasian yang berasal dari simplisia harus memenuhi persyaratan yang telah ditetapkan untuk dapat menjadi obat herbal terstandar atau obat fitofarmaka. Salah satu parameter mutu ekstrak secara kimia adalah kandungan senyawa aktif simplisia tersebut. Selain itu, parameter non spesifik juga diperlukan untuk 
mengetahui mutu ekstrak. Oleh karena itu, penelitian ini juga bertujuan untuk membandingkan beberapa nilai parameter ekstrak secara non spesifik pada ekstrak etanol dan ekstrak terpurifikasi rimpang kunyit. Dalam penelitian ini pengujian parameter non spesifik mengacu pada persyaratan yang sudah ditetapkan BPOM RI sehingga dibatasi pada nilai parameter yang telah ada yaitu penetapan kadar air, kadar abu, dan kadar abu tidak larut asam.

Hasil penelitian ini diharapkan dapat memberikan informasi kadar kurkumin dan beberapa nilai parameter mutu ekstrak pada ekstrak etanol dan ekstrak terpurifikasi rimpang kunyit dan mengetahui manakah yang lebih baik sehingga dapat digunakan sebagai acuan dalam penelitian berikutnya maupun penggunaan sebagai pengobatan.

\section{METODE PENELITIAN}

\section{A. Alat dan Bahan}

Alat-alat yang digunakan dalam penelitian ini adalah timbangan analitik, alat-alat gelas laboratorium, krus silikat, kertas saring bebas abu, alat destilasi, bejana kromatografi, pipa kapiler, lampu UV 254 nm, TLC-scanner, mikropipet, alat pendingin balik.

Rimpang kunyit yang diambil dari daerah Kulonprogo, Yogyakarta, fluorogusin LP, kloralhidrat LP, aquadest, etanol $\mathrm{P}$, Silika gel $60 \mathrm{~F}_{254}$, kloroform P-Metanol P (95:5), heksan P-etil asetat P (1:1). Pereaksi toluen jenuh air untuk penetapan kadar air.

\section{B. Jalannya Penelitian}

\section{Determinasi Tanaman}

Tanaman yang digunakan dideterminasi di Laboratorium Ilmu Alam Fakultas MIPA Universitas Ahmad Dahlan Yogyakarta.

\section{Pembuatan Ekstrak Etanol dan Ekstrak Terpurifikasi Rimpang Kunyit}

Ekstrak etanol kunyit dibuat dengan metode maserasi menggunakan cairan penyari etanol $96 \%$. Maserat diperoleh kemudian pelarutnya diuapkan dengan menggunakan rotary evaporator pada suhu $50^{\circ} \mathrm{C}$ sampai diperoleh ekstrak cair, penguapan dilanjutkan di atas waterbath pada suhu terjaga $50^{\circ} \mathrm{C}$ sampai diperoleh esktrak kental.

Pembuatan ekstrak terpurifikasi kunyit dilakukan dengan merendam $20 \mathrm{~g}$ ekstrak etanol kunyit dengan n-heksan sampai ekstrak kental cukup terendam, diaduk terus dan dipisahkan cairan dari endapannya. Cairan n-heksan ini dipisahkan karena diharapkan n-heksan mampu menyari resin dan terpenoid penyusun minyak atsiri, sehingga ekstrak yang didapatkan merupakan ekstrak kunyit terpurifikasi. Pelarutan dengan n-heksan diulangi sebanyak 5-10 kali hingga diperoleh cairan tak berwarna atau terlihat jernih. Setelah cairan n-heksan cukup jernih kemudian dipisahkan dari endapan dengan cara didekantir dan dibiarkan hingga sisa n-heksan pada endapan menguap sehingga diperoleh ekstrak terpurifikasi. Ekstrak terpurifikasi yang diperoleh 
berbentuk ekstrak yang lebih padat dan keras berwarna coklat.

\section{Penetapan Kadar Kurkumin}

a. Pembuatan larutan uji

Masing-masing sebanyak 10,0 mg ekstrak etanol dan ekstrak terpurifikasi kunyit dilarutkan dalam 10,0 ml etanol p.a dalam labu ukur 10,0 ml.

b. Pembuatan larutan pembanding

Kurkumin 0,1\% dalam etanol $\mathrm{P}$, dibuat seri kadar hingga diperoleh serapan yang mendekati serapan larutan uji.

\section{c. Profil Kromatografi}

Kromatografi Lapis Tipis yang digunakan yaitu Silika gel 60 F254 dengan fase gerak kloroform : etanol : asam asetat glasial (94:5:1) dan dideteksi dibawal lampu UV $366 \mathrm{~nm}$.

\section{d. Pengukuran}

Masing-masing $5 \mu \mathrm{L}$ larutan uji dan seri kadar larutan pembanding ditotolkan pada lempeng fase diam dan dielusi dengan fase gerak diukur secara KLT-Densitometri, pada panjang gelombang $426 \mathrm{~nm}$.

\section{Pengujian Parameter Non Spesifik Ekstrak}

Pengujian parameter standard ekstrak dilakukan sesuai acuan Badan POM dan hasilnya dibandingkan dengan persyaratan yang tertera pada buku Monografi Ekstrak Tumbuhan Obat Indonesia yang bertujuan untuk membandingkan hasil pengujian parameter non spesifik antara ekstrak etanol dan ekstrak terpurifikasi. Metode uji parameter non spesifik meliputi penetapan kadar air dan kadar abu yang terdiri dari kadar abu total dan kadar abu tak larut asam.

\section{HASIL DAN PEMBAHASAN}

Pengambilan simplisia dilakukan di satu tempat yaitu daerah Kulonprogo Yogyakarta pada bulan Maret 2012. Hal ini dilakukan untuk menghindari variasi kandungan zat aktif dalam tanaman karena adanya perbedaan daerah tumbuh, waktu panen, dan proses pasca panen.

Penyarian ini menggunakan etanol $96 \%$ sebagai penyari karena etanol adalah pelarut semi polar dan mampu menyari sebagian besar kandungan kimia dari simplisia tersebut. Dalam hal penyarian, etanol memiliki kelebihan dibandingkan dengan air dan metanol. Senyawa kimia yang mampu disari dengan etanol lebih banyak dari pada penyari metanol dan air. Kandungan kurkumin dari ekstrak etanol adalah 3-5\% sedangkan dari penyari methanol maupun air jauh di bawah itu (Pandey, et al, 2010).

\section{Uji Kualitatif dan Kuantitatif Kurkumin}

Analisis kromatografi lapis tipis (KLT) kualitatif dan kuantitatif kurkumin menggunakan fase diam lempeng silika gel $69 \mathrm{~F}_{254}$ dan fase gerak kloroform : etanol : asam asetat glasial (94: $5: 1 \mathrm{v} / \mathrm{v})$. Sebelum dilakukan penotolan sampel, fase diam harus diaktifkan dengan cara dipanaskan terlebih dahulu dalam oven pada suhu $110^{\circ} \mathrm{C}$ selama 15 menit. Hal ini 
bertujuan untuk meningkatkan daya absorbsi dari fase diam.

Pembuatan kurva baku bertujuan untuk mengetahui hubungan antara konsentrasi dengan luas area. Larutan standar dibuat dengan konsentrasi 0,2 ; 0,$4 ; \quad 0,8 ; 1,2 ; 1,4 ; \quad$ dan $1,6 \mu \mathrm{g} / \mu \mathrm{l}$. Sedangkan larutan sampel dibuat dengan konsentrasi $10 \mathrm{mg} / \mathrm{ml}$ dengan volume penotolan sebanyak $5 \mu$ l. Sebelum dilakukan pengembangan, bejana pengembang dijenuhkan dengan uap fase gerak agar pemisahan sampel dapat optimal dan untuk mempercepat elusi. Profil kromatografinya terlihat pada Gambar 1.

Menurut pengamatan dengan UV $366 \mathrm{~nm}$ (Gambar 1), deteksi tidak digunakan dengan pereaksi semprot karena kurkumin sudah berwarna jika dilihat pada UV $366 \mathrm{~nm}$. Pada pengamatan dengan UV $366 \mathrm{~nm}$ terdapat bercak dengan $\mathrm{Rf} 0,51$ (bercak 1) baik pada pembanding kurkumin maupun bercak ekstrak etanol dan ekstrak terpurifikasi. Bercak tersebut merupakan senyawa kurkumin karena adanya kesamaan warna dan nilai Rf pada masing-masing bercak ekstrak dan pembanding kurkumin. Pada sampel masing-masing ekstrak terdapat bercak dengan nilai $\operatorname{Rf} 0,36$ (bercak 2) yang merupakan senyawa demetoksi kurkumin dan bercak dengan nilai Rf 0,25 (bercak 3) yang merupakan senyawa bisdemetoksi kurkumin. Kurkuminoid dalam rimpang kunyit meliputi senyawa kurkumin, demetoksi kurkumin dan bisdemetoksi kurkumin. Bercak senyawa demetoksi kurkumin dan bisdemetoksi kurkumin tidak ditemukan pada pembanding kurkumin.

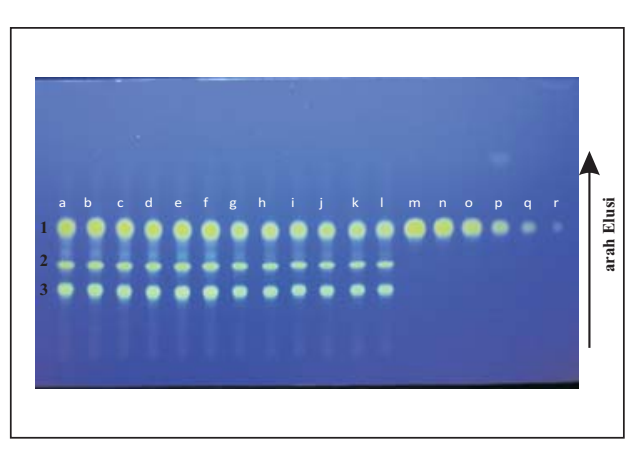

Gambar 1. Profil KLT ekstrak etanol, ekstrak terpurifikasi dan kurkumin standar

Keterangan :

\begin{tabular}{|c|c|}
\hline Bercak $1(\operatorname{Rf} 0,51)$ & $=$ senyawa kurkumin \\
\hline Bercak $2(\operatorname{Rf} 0,36)$ & $\begin{aligned}= & \text { senyawa demetoksi } \\
& \text { kurkumin }\end{aligned}$ \\
\hline Bercak $3(\operatorname{Rf} 0,25)$ & $\begin{aligned}= & \text { senyawa } \\
& \text { bisdemetoksi } \\
& \text { kurkumin. }\end{aligned}$ \\
\hline Bercak $a-f$ & $=\underset{\text { terpurifikasi }}{\text { ekstrak }}$ \\
\hline Bercak g - 1 & $=$ ekstrak etanol \\
\hline Bercak m - r & $\begin{aligned}= & \text { standar kurkumin } \\
& 1.6 ; 1.4 ; 1.2 ; 0.8 ; \\
& 0.4 \text { dan } 0.2 \mu \mathrm{g} / \mu \mathrm{l}\end{aligned}$ \\
\hline Fase gerak & $\begin{aligned}= & \text { kloroform : etanol : } \\
& \text { asam asetat glasial } \\
& (94: 5: 1)\end{aligned}$ \\
\hline Fase diam & $=$ Silica gel $60 \mathrm{~F}_{254}$ \\
\hline
\end{tabular}

Selanjutnya dilakukan penetapan kadar kurkumin setelah analisis kualitatif kurkumin. Cara penetapan kadar kurkumin yaitu dengan scanning pelat KLT secara mendatar pada bercak senyawa kurkumin seluruh sampel yang ditotolkan yaitu pada $\mathrm{Rf}$ 0,51. Data densitometri ini berupa luas area bercak yang terdeteksi oleh sinar UV dengan panjang gelombang $425 \mathrm{~nm}$. Panjang gelombang $425 \mathrm{~nm}$ merupakan panjang 
gelombang maksimum untuk senyawa kurkumin. Penetapan linearitas dilakukan dengan cara meregresikan kadar versus luas area seri larutan kurkumin standar sehingga didapat persamaan kurva baku y $=20434,6525 \mathrm{x}$ $+1348,6576$

Untuk $\mathrm{n}=6$ dengan taraf kepercayaan 95\% maka harga $\mathrm{r}_{\text {-tabel }}=$ 0,632 dan untuk taraf kepercayaan 99\% harga $r_{\text {tabel }}=0,8114$ (Riwidikdo, 2008) kesimpulannya $\mathrm{r}_{\text {-hitung }}=0,9963>\mathrm{r}_{\text {tabel }}=$ 0,8114 maka dikatakan korelasi bermakna (signifikan) dan persamaan regresi linier $\mathrm{y}=20434,6525 \mathrm{x}+$ 1348,6576 dari larutan standar kurkumin menunjukkan adanya hubungan yang signifikan antara konsentrasi larutan standar kurkumin dengan luas area. Kurva hubungan antara konsentrasi

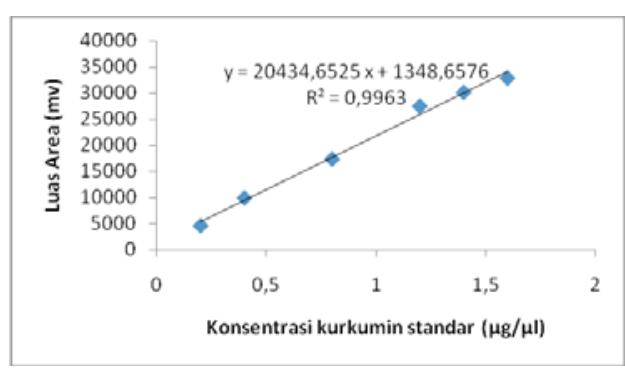

Gambar 2. Kurva hubungan konsentrasi kurkumin dengan luas area pada kurkumin pembanding

dengan luas area larutan standar kurkumin dapat dilihat pada Gambar 2.

Kadar kurkumin dari masingmasing ekstrak diperoleh dengan memasukkan harga luas area sampel ke

Tabel I. Hasil penetapan kadar kurkumin dalam ekstrak etanol dan ekstrak terpurifikasi rimpang kunyit secara densitometri

\begin{tabular}{|c|c|c|c|c|c|c|c|}
\hline Sampel & $\begin{array}{c}\text { Berat } \\
\text { sampel } \\
(\mathbf{m g})\end{array}$ & hRf & $\begin{array}{c}\text { Luas } \\
\text { area } \\
\text { sampel } \\
(\mathbf{m v})\end{array}$ & $\begin{array}{c}\text { Kadar } \\
\text { kurkumin } \\
(\mu \mathrm{g} / \mu \mathrm{l})\end{array}$ & $\begin{array}{c}\text { Kadar } \\
\text { kurkumin } \\
(\% \text { b/b })\end{array}$ & $\begin{array}{c}\overline{\mathbf{X}} \pm \mathrm{SD} \\
(\mathbf{\%})\end{array}$ & CV $(\%)$ \\
\hline \multirow[t]{6}{*}{ Ekstrak etanol } & 10,00 & 51 & 22043,3 & 1,0127 & 20,25 & \multirow{6}{*}{$\begin{array}{c}19,628 \\
\quad \pm \\
0,6105\end{array}$} & \multirow{6}{*}{3,11} \\
\hline & 10,00 & 51 & 21195,9 & 0,9713 & 19,43 & & \\
\hline & 10,00 & 51 & 20367,1 & 0,9307 & 18,61 & & \\
\hline & 10,00 & 51 & 21750,4 & 0,9984 & 19,97 & & \\
\hline & 10,00 & 51 & 21165,7 & 0,9698 & 19,40 & & \\
\hline & 10,00 & 51 & 21899,2 & 1,0057 & 20,11 & & \\
\hline \multirow{6}{*}{$\begin{array}{l}\text { Ekstrak } \\
\text { terpurifikasi }\end{array}$} & 10,00 & 51 & 27045,1 & 1,2575 & 25,15 & \multirow{6}{*}{$\begin{array}{c}26,217 \\
\pm \\
1,3022\end{array}$} & \multirow{6}{*}{4,96} \\
\hline & 10,00 & 51 & 27789,8 & 1,2939 & 25,88 & & \\
\hline & 10,00 & 51 & 26472,1 & 1,2295 & 24,59 & & \\
\hline & 10,00 & 51 & 28143,1 & 1,3112 & 26,22 & & \\
\hline & 10,00 & 51 & 29659,7 & 1,3854 & 27,71 & & \\
\hline & 10,00 & 51 & 29703,0 & 1,3876 & 27,75 & & \\
\hline
\end{tabular}


dalam persamaan regresi linier dari kurva baku sehingga diperoleh kadar kurkumin dalam sampel dalam satuan $\mu \mathrm{g} / \mu \mathrm{l}$, kemudian dikonversikan dalam satuan $\%$ b $/ \mathrm{b}$ dari $10 \mathrm{mg}$ ekstrak. Hasil penetapan kadar kurkumin pada masingmasing ekstrak yang ditetapkan secara densitometri ditampilkan dalam Tabel I.

Kadar kurkumin dalam ekstrak etanol dan ekstrak terpurifikasi rimpang kunyit diuji distribusi normal (Kolmogrov-Smirnov) dan homogenitas variannya (Levene Test) dengan taraf kepercayaan 96\%. Hasil uji distribusi normal tersebut memberikan harga signifikasi sebesar 0.334 lebih besar dari 0,05 sehigga dapat disimpulkan bahwa data terdistribusi normal. Pada uji homogenitas varian dengan uji Levene diperoleh harga signfikasi 0.116 lebih besar dari 0,05 sehingga dapat disimpulkan bahwa data memiliki variasi yang homogen. Data tersebut memenuhi syarat untuk uji ANOVA yaitu data terdistribusi normal dan memiliki variasi yang homogen.Uji ANOVA dilakukan dengan uji $t$ (LSD) dan dari nilai signifikasi dapat disimpulkan bahwa terdapat perbedaan bermakna pada kadar kurkumin dari masing-masing ekstrak.

Dari hasil penelitian ini diperoleh kesimpulan bahwa kadar kurkumin pada ekstrak etanol dan ekstrak terpurifikasi rimpang kunyit berbeda secara bermakna. Ekstrak etanol rimpang kunyit yang terpurifikasi memiliki kadar kurkumin yang lebih tinggi karena mengandung zat pengotor atau zat balast yang lebih kecil daripada ekstrak etanol yang tidak terpurifikasi. Hal ini dapat dimanfaatkan untuk mendapatkan efek farmakologi yang lebih baik karena ekstrak terpurifikasi memiliki kandungan kurkumin yang lebih tinggi dengan membatasi sekecil mungkin zat balast yang ikut tersari dalam ekstrak sehingga dapat mengurangi efek yang tidak diinginkan dari penggunaan ekstrak dalam pengobatan.

\section{Pengujian Parameter Non Spesifik Ekstrak}

\section{a. Kadar Air}

Penetapan kadar air di dalam ekstrak, dilakukan secara destilasi. Tujuan penetapan kadar air adalah mengetahui besarnya kandungan air, terkait dengan kemurnian dan kontaminasi yang mungkin terjadi.

Dari hasil tersebut diketahui bahwa ekstrak etanol rimpang kunyit yang diuji mempunyai kisaran kadar air $6,0-7,0 \% \mathrm{v} / \mathrm{b}$, sedangkan ekstrak terpurifikasi mempunyai kadar air 2,0\% $\mathrm{v} / \mathrm{b}$. Kandungan air maksimal yang di-

Tabel II. Kadar air ekstrak etanol dan ekstrak terpurifikasi kunyit

\begin{tabular}{|l|c|c|c|c|}
\hline \multirow{2}{*}{\multicolumn{1}{c|}{ Sampel }} & \multicolumn{4}{|c|}{ Kadar Air (\% v/b) } \\
\cline { 2 - 5 } & Sampel 1 & Sampel 2 & Sampel 3 & Purata \pm SD \\
\hline Ekstrak etanol & 6,0 & 7,0 & 6,0 & 6,3 \\
\hline Ekstrak terpurifikasi & 2,0 & 2,0 & 2,0 & 2,0 \\
\hline
\end{tabular}


perbolehkan terdapat di dalam ekstrak rimpang kunyit dalam buku Monografi Ekstrak Tumbuhan Obat Indonesia adalah 4,0\%. Kadar air dalam ekstrak terpurifikasi telah memenuhi persyaratan sedangkan ekstrak etanol melebihi persyaratan. Berdasarkan analisis varian yang dilakukan terhadap data ini, diketahui terdapat perbedaan yang bermakna pada kadar air dari masingmasing ekstrak.

\section{b. Kadar Abu}

Penetapan kadar abu total dan kadar abu tak larut asam dilakukan dengan pengabuan ekstrak dalam krus di dalam tanur pada suhu $800^{\circ} \mathrm{C}$. Disini terjadi pemanasan bahan pada temperatur dimana senyawa organik dan turunannya terdestruksi dan menguap, sehingga yang tertinggal hanya unsur mineral dan anorganik. Tujuannya adalah untuk memberikan gambaran kandungan mineral internal dan eksternal yang berasal dari proses awal sampai terbentuknya ekstrak. Selain itu penetapan kadar abu juga dimaksudkan untuk mengontrol jumlah pencemar benda-benda organik seperti tanah, pasir yang seringkali terikut dalam sediaan nabati. Kadar abu total yang diperbolehkan dalam ekstrak rimpang kunyit tidak lebih dari 0,4\% dan kadar abu tidak larut asam tidak lebih dari 0,08 \%.

Dari hasil penetapan yang diperoleh diketahui bahwa kadar abu total ekstrak etanol rimpang kunyit rata-rata adalah $2,41 \% \mathrm{~b} / \mathrm{b}$ dan ekstrak terpurifikasi sebesar $4,10 \%$ b/b. Kadar abu tidak larut asam ekstrak etanol rimpang kunyit adalah $0,05 \% \mathrm{~b} / \mathrm{b}$ dan ekstrak terpurifikasi $0,08 \%$ b/b. Kadar abu total pada masing-masing ekstrak belum memenuhi persyaratan dan kadar abu tidak larut asam untuk masing-masing ekstrak sudah memenuhi persyaratan.

Tabel III. Kadar abu total ekstrak etanol dan ekstrak terpurifikasi kunyit

\begin{tabular}{|l|c|c|c|c|}
\hline \multirow{2}{*}{\multicolumn{1}{c}{ Sampel }} & \multicolumn{4}{|c|}{ Kadar Abu Total (\% v/b) } \\
\cline { 2 - 5 } & $\mathbf{1}$ & $\mathbf{2}$ & $\mathbf{3}$ & Purata \pm SD \\
\hline Ekstrak etanol & 2,40 & 2,41 & 2,42 & 2,41 \\
\hline Ekstrak terpurifikasi & 4,10 & 4,11 & 4,10 & 4,10 \\
\hline
\end{tabular}

Tabel IV. Kadar abu tidak larut asam ekstrak etanol dan ekstrak terpurifikasi kunyit

\begin{tabular}{|l|c|c|c|c|}
\hline \multirow{2}{*}{\multicolumn{2}{c}{ Sampel }} & \multicolumn{4}{|c|}{ Kadar Abu Tidak Larut Asam (\% v/b) } \\
\cline { 2 - 5 } & $\mathbf{1}$ & $\mathbf{2}$ & $\mathbf{3}$ & Purata \pm SD \\
\hline Ekstrak etanol & 0,05 & 0,05 & 0,05 & 0,05 \\
\hline Ekstrak terpurifikasi & 0,07 & 0,08 & 0,08 & 0,08 \\
\hline
\end{tabular}


Berdasarkan analisis varian yang dilakukan terhadap data tersebut, ada perbedaan yang bermakna antara kadar abu total ekstrak etanol dan ekstrak terpurifikasi rimpang kunyit. Kadar abu tidak larut asam antara kedua ekstrak tersebut terdapat perbedaan yang tidak bermakna.

\section{KESIMPULAN}

Kadar kurkumin ekstrak etanol dan ekstrak terpurifikasi rimpang kunyit berbeda secara signifikan. Ekstrak etanol yang terpurifikasi memiliki kadar kurkumin yang lebih tinggi. Nilai parameter non spesifik meliputi kadar air, kadar abu total, kadar abu tidak larut asam pada masing-masing ekstrak memiliki perbedaan yang bermakna.

\section{DAFTAR PUSTAKA}

Aggarwal,Young-Joon Surh, Shishir Shishodia, 2008, The Molecular Targets and Therapeutic Uses of Curcumin in Health and Disease, 464, Springer Science+Business Media, LLC, Spring Street, New York, USA.

Anand, Sundaram, Jhurani, Kunnumakkara and Aggarwal, 2008, Curcumin and Cancer: An Old-Age Disease with an Age-Old Solution, Cancer Letters, 1 (267) : 133-164.

Araujo, and Leon, 2001, Biological Activities of Curcuma longa L., MemInst Oswaldo Cruz, Rio de Janeiro, 96 (5): 723-28.
BPOM, 2010a, Acuan Sediaan Herbal Volume V Edisi 1. BPOM RI, Jakarta.

BPOM, 2010b, Monografi Ekstrak Tumbuhan Indonesia, Direktorat Standardisasi Obat Trandisional, Kosmetik dan Produk Komplemen BPOM RI, Jakarta.

Depkes, 2008, Farmakope Herbal Indonesia, Departemen Kesehatan Republik Indonesia, Jakarta.

Jayaprakasha, G.K., Jagan Mohan Rao, L., dan Sakariah, K. K, 2006, Antioxidant Activities of Curcumin. Demethoxycurcumin and Bisdemethoxycurcumin, Food Chemistry, 98, 720-724.

Niazi, Priyanka Poonia, Vikas Gupta, Narinderpal Kaur, 2010, Pharmacotherapeutics Of Curcuma Longa-A Potent Patent, International Journal of Pharma Professional's Research, 1: 24-30.

Pandey, Sanjay. Katiyar, 2010, Determination and Comparison of The Curcuminoid Pigments in Turmeric Genotypes (Curcuma Domestica Val) by Highperformance Liquid Chromatography, International Journal of Pharmacy and Pharmaceutical Sciences, 2 (4) : 125-127.

Pothitirat, and Wandee Gritsanapan, 2005, Quantitative Analysis of Curcumin, Demethoxycurcumin 
and Bisdemethoxycurcumin in the Crude Curcuminoid Extract from Curcuma longa in Thailand by TLC Densitometry, Mahidol University Journal of Pharmaceutical Sciences, 32(1-2): 23-30. 